\title{
Sensitive Quantitative Predictions of MHC Binding Peptides and Fragment Based Peptide Vaccines from Taenia crassiceps
}

\section{Gomase VS* and Chitlange NR}

Department of Bioinformatics, JJT University, Jhunjhunu Rajasthan, 333001, India

\begin{abstract}
Taenia crassiceps is a member of the Taenia genus. It is a tapeworm. It is related to Taenia solium, the pork tapeworm, and to Taenia saginata, the beef tapeworm. Its larvae eat tiny holes in the human retina, eventually detaching it. The life cycle is when an adult lays eggs inside a wild canine. Peptide fragments of antigen protein can be used to select nonamers for use in rational vaccine design and to increase the understanding of roles of the immune system in infectious diseases. Analysis shows MHC class II binding peptides of antigen protein from Taenia crassiceps are important determinant for protection of host form parasitic infection. In this assay, we used PSSM and SVM algorithms for antigen design and predicted the binding affinity of antigen protein having 72 amino acids, which shows 64 nonamers. Binding ability prediction of antigen peptides to major histocompatibility complex (MHC) class I \& II molecules is important in vaccine development from Taenia crassiceps.
\end{abstract}

Keywords: Antigen protein; Epitope; PSSM; SVM; MHC; Peptide vaccine

Abbreviations: GES: Goldman; Engelberg and Steitz; MHC: Major Histocompatibility Complex; PSSMs: Position Specific Scoring Matrices; SVM: Support Vector Machine

\section{Introduction}

Trichinella species are the smallest nematode parasite of humans; have an unusual life cycle and are one of the most widespread and clinically important parasites in the world [1]. The small adult worms mature in the intestines of an intermediate host such as a pig [1,2]. Taenia crassiceps antigen peptides are most suitable for subunit vaccine development because with single epitope; the immune response can be generated in large population. This approach is based on the phenomenon of cross-protection; whereby infected with a mild strain and is protected against a more severe strain of the same. The phenotype of the resistant transgenic hosts includes fewer centers of initial infection; a delay in symptom development; and low accumulation. Antigen protein from Taenia crassiceps is necessary for new paradigm of synthetic vaccine development and target validation [3-5].

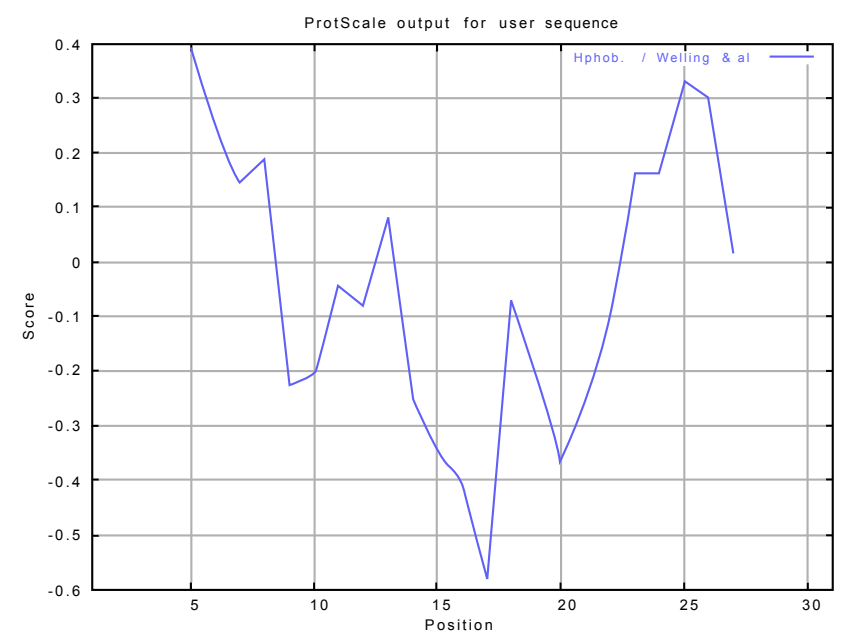

Figure 1: Hydrophobicity plot of antigen protein by Hphob / Welling \& al., scale.

\section{Methodology}

In this research work antigenic epitopes of antigen protein from Taenia crassiceps is determined using the Gomase in 2007; Welling; Eisenberg; Parker and Chou \& Fasman and Levitt antigenicity [68]. The major histocompatibility complex (MHC) peptide binding of antigen protein is predicted using neural networks trained on $\mathrm{C}$ terminals of known epitopes. In analysis predicted $\mathrm{MHC} /$ peptide binding of antigen protein is a log-transformed value related to the

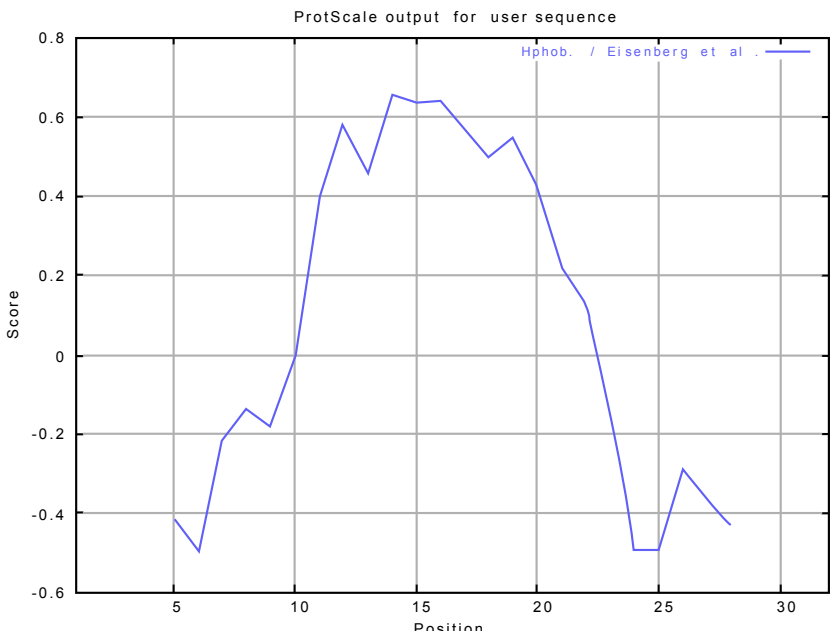

Figure 2: Hydrophobicity plot of antigen protein by Hphob/ Eisenberg, et al., scale.

*Corresponding author: Gomase VS, Department of Bioinformatics, JJT University, Jhunjhunu Rajasthan, 333001, India; E-mail: gomase.viren@gmail.com Received September 11, 2011; Accepted March 29, 2012; Published March 30, 2012

Citation: Gomase VS, Chitlange NR (2012) Sensitive Quantitative Predictions of MHC Binding Peptides and Fragment Based Peptide Vaccines from Taenia crassiceps. J Vaccines Vaccin 3:131. doi:10.4172/2157-7560.1000131

Copyright: (c) 2012 Gomase VS, et al. This is an open-access article distributed under the terms of the Creative Commons Attribution License, which permits unrestricted use, distribution, and reproduction in any medium, provided the original author and source are credited. 
Citation: Gomase VS, Chitlange NR (2012) Sensitive Quantitative Predictions of MHC Binding Peptides and Fragment Based Peptide Vaccines from Taenia crassiceps. J Vaccines Vaccin 3:131. doi:10.4172/2157-7560.1000131

Page 2 of 4

\begin{tabular}{|c|c|c|c|c|c|c|c|}
\hline MHC-I & POS. & $\mathrm{N}$ & Sequence & C & MW (Da) & Score & $\%$ OPT. \\
\hline 8mer_H2_Db & 220 & LNE & LEEDFRTI & LSI & 1004.12 & 16.314 & $31.08 \%$ \\
\hline 8mer_H2_Db & 95 & RQV & AQYNNFSI & FSK & 938.01 & 13.407 & $25.54 \%$ \\
\hline 8mer_H2_Db & 44 & ICQ & FNLRCLEF & LKS & 1023.23 & 9.894 & $18.85 \%$ \\
\hline 8mer_H2_Db & 38 & KAV & PSLICQFN & LRC & 903.07 & 9.7 & $18.48 \%$ \\
\hline 8mer_H2_Db & 139 & $\mathrm{DHL}$ & PINPEVKI & SNG & 891.08 & 8.916 & $16.98 \%$ \\
\hline 8mer_H2_Db & 322 & PVS & RKAGPMTY & QML & 905.08 & 8.704 & $16.58 \%$ \\
\hline 8mer_H2_Db & 96 & QVA & QYNNFSIF & SKK & 1014.11 & 8.63 & $16.44 \%$ \\
\hline 9mer_H2_Db & 63 & EMY & FMLCLIDHI & ISN & 1086.38 & 20.064 & $39.84 \%$ \\
\hline 9mer_H2_Db & 95 & RQV & AQYNNFSIF & SKK & 1085.19 & 19.926 & $39.56 \%$ \\
\hline 9mer_H2_Db & 130 & MEL & FAHWSKDHL & PIN & 1099.25 & 19.277 & $38.27 \%$ \\
\hline 9mer_H2_Db & 44 & ICQ & FNLRCLEFL & KSY & 1136.39 & 15.072 & $29.93 \%$ \\
\hline 9mer_H2_Db & 41 & PSL & ICQFNLRCL & EFL & 1091.36 & 13.216 & $26.24 \%$ \\
\hline 9mer_H2_Db & 38 & KAV & PSLICQFNL & $\mathrm{RCL}$ & 1016.23 & 11.437 & $22.71 \%$ \\
\hline 9mer_H2_Db & 184 & GYD & QLIKNAREL & YTE & 1066.27 & 11.399 & $22.63 \%$ \\
\hline 10mer_H2_Db & 306 & VSP & SILKPLADYG & ILN & 1058.25 & 22.969 & $39.02 \%$ \\
\hline 10mer_H2_Db & 94 & $\mathrm{FRQ}$ & VAQYNNFSIF & SKK & 1184.32 & 19.021 & $32.32 \%$ \\
\hline 10mer_H2_Db & 73 & HII & SNYEPFRKGF & ATK & 1226.37 & 16.158 & $27.45 \%$ \\
\hline 10mer_H2_Db & 95 & RQV & AQYNNFSIFS & KKN & 1172.27 & 16.055 & $27.28 \%$ \\
\hline 10mer_H2_Db & 206 & SIF & NGEINEKEKA & ELN & 1113.19 & 15.416 & $26.19 \%$ \\
\hline 10mer_H2_Db & 9 & LVK & SAIDNEEVNP & SLH & 1069.1 & 11.88 & $20.18 \%$ \\
\hline 10mer_H2_Db & 70 & LID & HIISNYEPFR & KGF & 1257.43 & 11.82 & $20.08 \%$ \\
\hline 11mer_H2_Db & 94 & $\mathrm{FRQ}$ & VAQYNNFSIFS & KKN & 1271.4 & 13.696 & $17.23 \%$ \\
\hline 11mer_H2_Db & 285 & DYS & KTETNYESYPV & QRE & 1312.4 & 10.441 & $13.13 \%$ \\
\hline 11mer_H2_Db & 322 & PVS & RKAGPMTYQML & EDD & 1277.56 & 9.568 & $12.04 \%$ \\
\hline 11mer_H2_Db & 57 & SYI & SRKEMYFMLCL & IDH & 1402.76 & 9.078 & $11.42 \%$ \\
\hline 11mer_H2_Db & 39 & AVP & SLICQFNLRCL & EFL & 1291.6 & 7.777 & $9.78 \%$ \\
\hline 11mer_H2_Db & 8 & ELV & KSAIDNEEVNP & SLH & 1197.27 & 6.901 & $8.68 \%$ \\
\hline 11mer_H2_Db & 58 & YIS & RKEMYFMLCLI & $\mathrm{DHI}$ & 1428.84 & 6.462 & $8.13 \%$ \\
\hline
\end{tabular}

Table 1: PSSM based prediction of MHC ligands, from whose C-terminal end is proteosomal cleavage sites.

\begin{tabular}{|c|c|c|c|c|}
\hline $\begin{array}{l}\text { MHC } \\
\text { ALLELE }\end{array}$ & Rank & Sequence & $\begin{array}{l}\text { Residue } \\
\text { No. }\end{array}$ & $\begin{array}{l}\text { Peptide } \\
\text { Score }\end{array}$ \\
\hline$I-A b$ & 1 & PSIKDLQRE & 39 & 0.967 \\
\hline$I-A b$ & 2 & NTLTNDKRV & 61 & 0.815 \\
\hline $\mathrm{I}-\mathrm{Ab}$ & 3 & LTLGVNTLT & 56 & 0.560 \\
\hline $1-A b$ & 4 & MLLTLGVNT & 54 & 0.534 \\
\hline I-Ad & 1 & LSAMLLTLG & 51 & 0.726 \\
\hline I-Ad & 2 & GAHFCGAMM & 3 & 0.570 \\
\hline I-Ad & 3 & GIGAHFCGA & 1 & 0.504 \\
\hline I-Ad & 4 & MAINDINGP & 11 & 0.465 \\
\hline I-Ag7 & 1 & INTAENIAC & 23 & 1.564 \\
\hline I-Ag7 & 2 & EINTAENIA & 22 & 1.461 \\
\hline I-Ag7 & 3 & FCGAMMAIN & 6 & 1.246 \\
\hline I-Ag7 & 4 & GIGAHFCGA & 1 & 1.198 \\
\hline RT1.B & 1 & TEINTAENI & 21 & 0.660 \\
\hline RT1.B & 2 & VEALSAMLL & 48 & 0.586 \\
\hline RT1.B & 3 & TLTNDKRVL & 62 & 0.365 \\
\hline RT1.B & 4 & TAENIACRA & 25 & 0.250 \\
\hline
\end{tabular}

Table 2: SVM based prediction of promiscuous MHC class II binding peptides from antigen protein.

IC50 values in nM units. MHC2Pred predicts peptide binders to MHCI and MHCII molecules from protein sequences or sequence alignments using Position Specific Scoring Matrices (PSSMs). Support Vector Machine (SVM) based method for prediction of promiscuous MHC class II binding peptides. SVM has been trained on the binary input of single amino acid sequence [9-14]. In addition; we predict those MHC ligands from whose C-terminal end is likely to be the result of proteosomal cleavage [15-18].

\section{Results and Interpretations}

We found binding of peptides to a number of different alleles using Position Specific Scoring Matrix. An antigen protein sequence is 44 residues long; having antigenic MHC binding peptides. MHC molecules are cell surface glycoproteins; which take active part in host immune reactions and involvement of MHC class-I and MHC II in response to almost all antigens. PSSM based server predict the peptide binders to MHCI molecules of antigen protein sequence are as 11 mer 


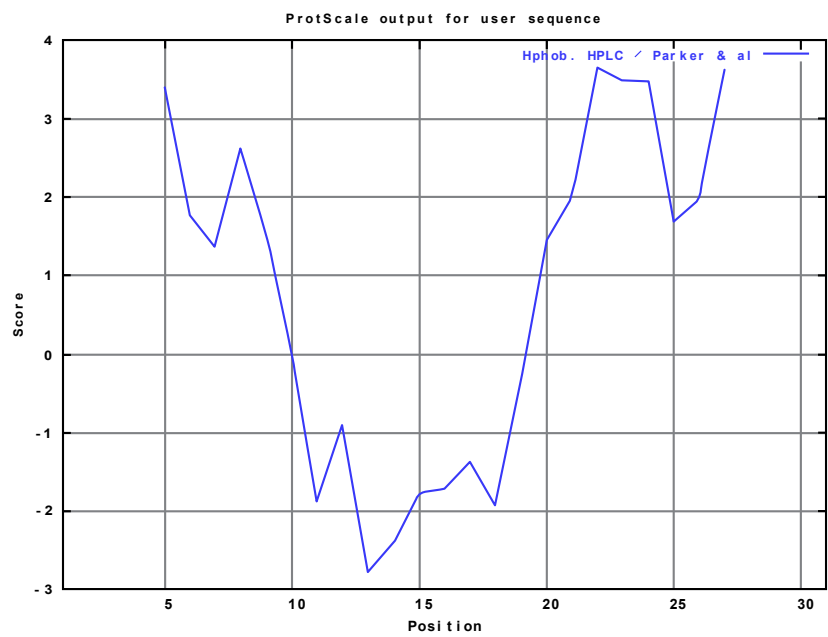

Figure 3: Hydrophobicity plot of antigen protein by Hphob. HPLC /Parker \& et al., scale.

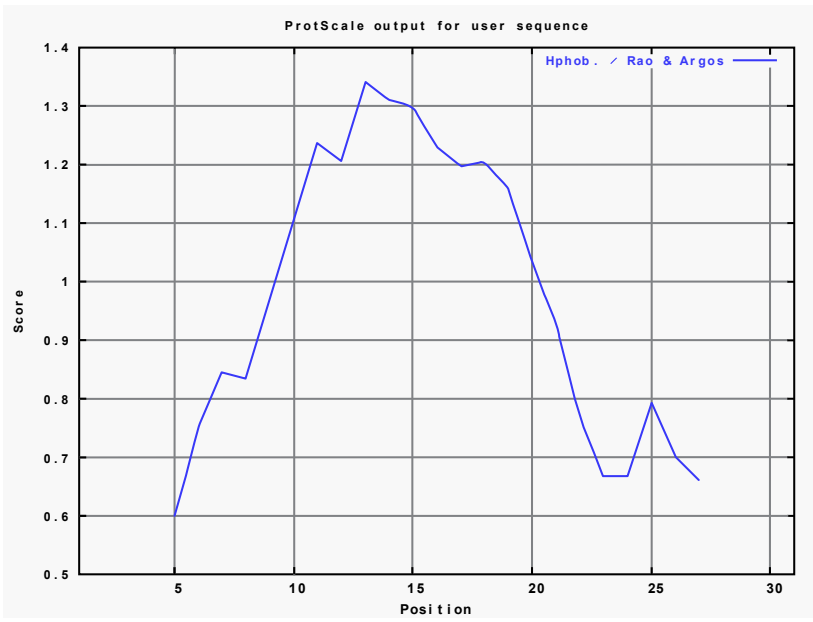

Figure 4: Antigenicity plot of antigen protein by Hphob. / Rao \& Argos, scale.

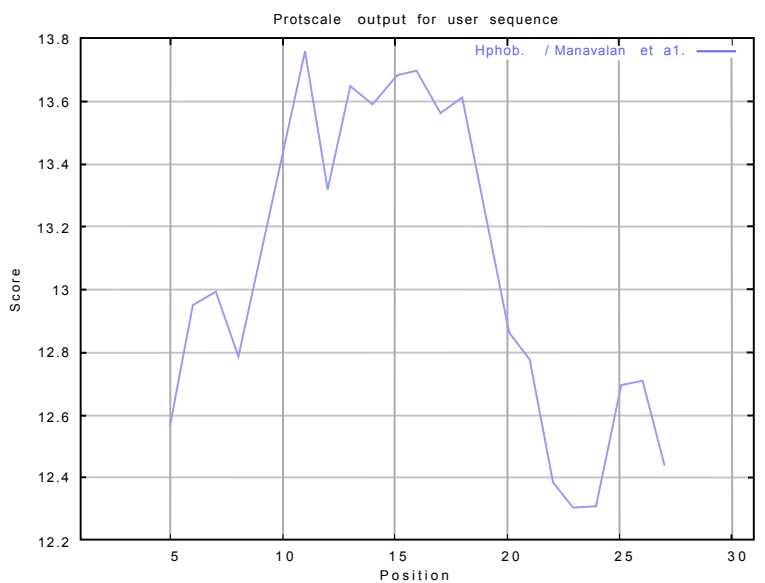

Figure 5: Antigenicity plot of antigen protein by Hphob. / Manavalan et al., scale.

H2_Db; 10mer_H2_Db; 9mer_H2_Db; 8mer_H2_Db and also peptide binders to MHCII molecules of antigen protein sequence as I_Ab.p;
I_Ad.p; analysis found antigenic epitopes region in putative antigen protein (Table 1). We also found the SVM based MHCII-IAb peptide regions; MHCII-IAd peptide regions; MHCII-IAg7 peptide regions and MHCII- RT1.B peptide regions; which represented predicted binders from bacterial antigen protein (Table 2). The predicted binding affinity is normalized by the $1 \%$ fractil. We describe an improved method for predicting linear epitopes (Table 2). The region of maximal hydrophilicity is likely to be an antigenic site; having hydrophobic characteristics; because a terminal region of antigen protein is solvent accessible and unstructured; antibodies against those regions are also likely to recognize the native protein (Figure 1, 2 and 3). It was shown that an antigen protein is hydrophobic in nature and contains segments of low complexity and high-predicted flexibility (Figure 4 and 5). Predicted antigenic fragments can bind to MHC molecule is the first bottlenecks in vaccine design.

\section{Conclusion}

An antigen protein from Taenia crassiceps peptide nonamers are from a set of aligned peptides known to bind to a given MHC molecule as the predictor of MHC-peptide binding. MHCII molecules bind peptides in similar yet different modes and alignments of MHCIIligands were obtained to be consistent with the binding mode of the peptides to their MHC class; this means the increase in affinity of MHC binding peptides may result in enhancement of immunogenicity of antigen protein. These predicted of antigen protein antigenic peptides to MHC class molecules are important in vaccine development from Taenia crassiceps.

\section{References}

1. Reyes JL, Espinoza-Jiménez AF, González MI, Verdin L, Terrazas LI (2011) Taenia crassiceps infection abrogates experimental autoimmune encephalomyelitis. Cell Immunol 267: 77-87.

2. Sciutto E, Fragoso G, Larralde C (2011) Taenia crassiceps as a model for Taenia solium and the S3Pvac vaccine. Parasite Immunol 33: 79-80.

3. Lightowlers MW (2010) Fact or hypothesis: Taenia crassiceps as a model for Taenia solium, and the S3Pvac vaccine. Parasite Immunol 32: 701-709.

4. McDonald D, Stockwin L, Matzow T, Blair Zajdel ME, Blair GE (1999) Coxsackie and adenovirus receptor (CAR)-dependent and major histocompatibility complex $(\mathrm{MHC})$ class I-independent uptake of recombinant adenoviruses into human tumour cells. Gene Ther 6: 1512-1519.

5. Gomase VS, Kale KV Shyamkumar K (2008) Prediction of MHC Binding Peptides and Epitopes from Groundnut Bud Necrosis Virus (GBNV). J Proteomics Bioinform 1: 188-205.

6. Gomase VS, Kale KV, Chikhale NJ, Changbhale SS (2007) Prediction of MHC Binding Peptides and Epitopes from Alfalfa mosaic virus. Curr Drug Discov Technol 4:117-215.

7. Gomase VS, Kale KV (2008) In silico prediction of epitopes: a new approach for fragment based viral peptide vaccines. Int J of Applied Computing 1: 39-46.

8. Gomase VS, Kale KV (2008) Approach of proteomics system architecture in plant virus's database. Int $\mathrm{J}$ of Applied Computing 1: 33-38.

9. Gomase VS, Kapoor RA, Ladak SS (2010) Eimeria acervulina analysis for binding peptides using protein profiling for target validation. International Journal of Machine Intelligence 2: 1-8.

10. Gomase VS, Kale KV, Shyamkumar K, Shankar S (2008) Computer Aided Multi Parameter Antigen Design: Impact of Synthetic Peptide Vaccines from Soybean Mosaic Virus. Emerging Trends in Engineering and Technology, 2008. ICETET '08, Nagpur, Maharashtra, 629-634

11. Gomase VS, Tandale JP, Patil SA, Kale KV (2006) Automatic modeling of protein 3D structure Nucleoplasmin-like viral coat protein from Cucumber mosaic virus. 14th International Conference on Advance Computing \& Communication, Published by IEEE Computer Society in IEEE Xplore USA 614-615 
Citation: Gomase VS, Chitlange NR (2012) Sensitive Quantitative Predictions of MHC Binding Peptides and Fragment Based Peptide Vaccines from Taenia crassiceps. J Vaccines Vaccin 3:131. doi:10.4172/2157-7560.1000131

12. Reche PA, Glutting JP, Reinherz EL (2002) Prediction of MHC Class I Binding Peptides Using Profile Motifs. Hum Immun 63: 701-709.

13. Buus S, Lauemøller SL, Worning P, Kesmir C, Frimurer T, et al. (2003) Sensitive quantitative predictions of peptide-MHC binding by a 'Query by Committee' artificial neural network approach. Tissue Antigens 62: 378-384.

14. Nielsen $M$, Lundegaard $C$, Worning $P$, Lauemøller SL, Lamberth $\mathrm{K}$, et al (2003) Reliable prediction of T-cell epitopes using neural networks with novel sequence representations. Protein Sci 12: 1007-1017.

15. Bhasin M, Raghava GP (2005) Pcleavage: an SVM based method for prediction of constitutive proteasome and immunoproteasome cleavage sites in antigenic sequences. Nucleic Acids Res 33: W202-207.
16. Gomase VS, Kapoor RA, Ladak SS (2010) Immuno-proteomics approach for synthetic vaccine development form Haemophilus influenzae. Journal of Infectious Diseases Letters 1: 01-06.

17. Gomase VS, Shyamkumar K (2009) Prediction of antigenic epitopes and MHC binders of neurotoxin alpha-KTx 3.8 from Mesobuthus tamulus sindicus. Afr J Biotechnol 8: 6658-6676.

18. Gomase VS, Kapoor RA, Ladak SS (2010) Computer intelligence approach for prediction of biding ability and fragment based peptide vaccines from Leishmania protozoa peptides. In proceeding of: 2010 International Conference on Software and Computing Technology (ICSCT 2010), USA 